\title{
Sprawozdanie z ogólnopolskiej konferencji „Między lękiem a nadzieja. 10 lat obowiązywania ustawy o mniejszościach narodowych i etnicz- nych oraz o języku regionalnym"
}

W dniach 7-8 maja 2015 roku odbyła się ogólnopolska konferencja zatytułowana „Między lękiem a nadzieją. 10 lat obowiązywania ustawy o mniejszościach narodowych i etnicznych oraz o języku regionalnym". Organizatorami tego przedsięwzięcia był Wydział Nauk Politycznych i Dziennikarstwa Uniwersytetu im. Adama Mickiewicza w Poznaniu oraz Urząd Marszałkowski Województwa Wielkopolskiego. Patronat nad konferencją objęli Komisja Mniejszości Narodowych i Etnicznych Sejmu RP i Wicewojewoda Wielkopolski.

Konferencja była kolejnym etapem oceny funkcjonowania ustawy o mniejszościach narodowych i etnicznych oraz o języku regionalnym. Pierwsza ewaluacja dokonana została w 2010 roku z okazji piątej rocznicy obowiązywania ww. ustawy na Wydziale Politologii Uniwersytetu im. Marii Curie Skłodowskiej w Lublinie. Na konferencji reprezentowane były najważniejsze ośrodki naukowe zajmujące się problematyką mniejszości, praktycy oraz przedstawiciele mniejszości.

Spotkanie otworzył Dziekan Wydziału Nauk Politycznych i Dziennikarstwa UAM prof. Tadeusz Wallas. Następnie uczestników konferencji powitali poseł Arkady Fiedler reprezentujący Komisję Mniejszości Narodowych i Etnicznych Sejmu RP oraz Dorota Kinal Wicewojewoda Wielkopolski. Obradom plenarnym przewodniczył prof. Andrzej Sakson. Pierwszym referentem był prof. Grzegorz Janusz z Uniwersytetu im. Marii Curie Skłodowskiej, który brał udział w pracach nad tworzeniem ustawy. W swoim wystąpieniu zajął się zatem genezą, stanem prawnym i perspektywami ochrony podmiotowej w ustawie o mniejszościach z dnia 6 stycznia 2005 roku. W ramach ostatniego z wymienionych zagadnień prof. G. Janusz stwierdził, iż coraz więcej społeczności chciałoby być objętych ochroną ustawową. Poza Ślązakami i Kaszubami wymienił także Greków. Za nowe zjawisko uznał pojawienie się w spisie powszechnym w 2011 roku kolejnych grup z pogranicza tj. kociewskiej, góralskiej, wielkopolskiej, mazurskiej, śląsko-cieszyńskiej, zagłębiowskiej, borowiackiej, mazowieckiej i kurpiowskiej. Wzrost świadomości odrębności osób zaliczających się do powyższych grup stawia przed ustawodawcą nowe wyzwania, podkreślił prof. G. Janusz. Kontynuacją wątku rozpoczętego przez prof. G. Janusza była problematyka dotycząca instytucjonalizacji praw osób należących do mniejszości po 1989 roku. Zagadnieniem tym zajął się reprezentant Uniwersytetu Warszawskiego prof. Sławomir Łodziński. Wyróżnił on trzy obszary, które w istotny sposób zaważyły na obecnym kształcie i charakterze ustawy. Wśród nich znalazły się: odejście od „obiektywnej” definicji mniejszości narodowej i przyjęcie zasady „opcji subiektywnej”, „umiędzynarodowienie” ochrony mniejszości poprzez odwoływanie się do standardów międzynarodowych i włączanie ich w system traktatów dwustronnych Polski z sąsiednimi państwami oraz „odpolitycznienie” polityki wobec społeczności mniejszościowych i nacisk na rozwój praw głównie w dziedzinie kultury i edukacji. Prof. S. Łodziński uznał wprowadzenie zmian w polityce wobec mniejszości w pierwszej połowie lat 90 . XX wieku za rewolucyjne w kontekście doświadczeń z przeszłości. To one, jak podkreślił, utorowały drogę do przyjęcia w 2005 roku ustawy o mniejszościach. Kolejny równie interesujący referat wygłosiła prof. Helena Duć-Fajfer z Uniwersytetu Jagiellońskiego. Swoje wystąpienie zatytułowała Paternalizm unikowy, czyli jak radzić sobie z ustawowymi zobowiqzaniami. Na przykładzie wybranych casusów z działania Komisji Wspólnej Rządu i Mniejszości Narodowych i Etnicznych dokonała próby analizy oraz oceny działań strony rządowej, do których Rząd RP został zobowiązany na mocy ustawy oraz ratyfikowanych dokumentów unijnych dotyczących mniejszości narodowych i etnicznych. Prof. H. Duć-Fajfer zaprezentowała dynamikę działań Komisji oraz wymieniła czynniki wpływające na skuteczność 
wdrażania w życie postulatów mniejszościowych wynikających z praw ustawowych (bądź ich brak). Referentka na zakończenie sformułowała wnioski wykazujące szereg ambiwalencji w polityce etnicznej prowadzonej przez rząd RP. Ostatnim prelegentem w pierwszej części obrad plenarnych był prof. Andrzej Sadowski z Uniwersytetu w Białymstoku. Jego referat dotyczył ustawy o mniejszościach w kontekście procesów narodowotwórczych na wschodnim pograniczu RP. Na początku profesor zaznaczył, iż ustawa została przygotowana z punktu widzenia państwa narodowego. Takie podejście skomplikowało relacje między większością a mniejszością. Następnie przeszedł do oceny ustawy zaznaczając, iż nie uwzględnia ona zjawisk i procesów dokonujących się wśród grup mniejszościowych oraz dróg rozwoju etnicznego (przeobrażania się grup mniejszości w dojrzały naród). Do podstawowych problemów profesor zaliczył nie uwzględnianie obecnie procesów narodowotwórczych zachodzących wewnątrz mniejszości. W drugiej części zajął się typologią przemian tożsamości mniejszości białoruskiej w Polsce. W swoim referacie prof. A. Sadowski sformułował także kilka propozycji udoskonalenia ustawy z 2005 roku. Pierwsza część konferencji została nagrana. Całość znajduje się na stronie https://www. youtube.com/watch?v=qAXPBxdxDpY.

W drugiej części obrad plenarnych, którą poprowadził prof. Grzegorz Janusz swoje referaty wygłosiło sześcioro prelegentów. Pierwszym z nich był reprezentujący gospodarzy prof. Andrzej Sakson, który zajął się mniejszościami nieuznanymi, czyli Ślązakami, Kaszubami, Mazurami i Warmiakami. Na początku swego wystappieniu stwierdził, iż w tradycji polskich badaczy socjologii narodu ludność rodzima uznawana jest za mniejszość etniczną. Następnie pokazał, iż ustawa z 2005 roku przyczyniła się do zróżnicowania statusu prawnego grup pogranicza społecznego. Doprowadziło to do ich podziału, wzrostu tendencji autonomicznych (np. działalność Ruchu Autonomii Śląska) oraz dążenia do uznania ich za odrębny naród (np. aktywność Stowarzyszenia Osób Narodowości Kaszubskiej). Jako drugi wystapił prof. Dariusz Matelski z Uniwersytetu im. Adama Mickiewicza w Poznaniu. W referacie zatytułowanym Ochrona dziedzictwa kulturowego mniejszości narodowych $w$ Polsce na mocy ustawy o mniejszościach narodowych z 2005 roku omówił przepisy prawne odnoszące się do ochrony dziedzictwa kulturowego mniejszości w III RP i przykłady ich realizacji w okresie obowiązywania ustawy. W swoim wystapieniu zaznaczył ponadto, iż współcześnie brakuje wytycznych do polityki narodowościowej. W dalszej kolejności wystąpiła dr Marzenna Giedrojć reprezentująca Uniwersytet Szczeciński. Swoją uwagę skupiła na kontroli organów i instytucji państwowych realizujących zadania wynikające z ustawy o mniejszościach przez Komisję Mniejszości Narodowych i Etnicznych Sejmu RP. Jak zaznaczyła, dr M. Giedrojć, w latach 2006-2015 kontrola dotyczyła przede wszystkim zadań z zakresu zachowania i rozwoju tożsamości kulturowej mniejszości narodowych i etnicznych oraz społeczności posługującej się językiem regionalnym. W ramach tych działań zainicjowano np. kontrolę wykorzystania środków z programu rządowego na rzecz społeczności romskiej w Polsce. Na koniec swojego wystapienia dr M. Giedrojć zaapelowała do posłów Komisji Mniejszości Narodowych i Etnicznych Sejmu RP, aby w ramach cyklicznych informacji składanych przez urzędników ministerstw realizujących politykę etniczną domagali się przedstawienia konkretnych działań podjętych przez te organy wobec postulatów składanych przez posłów na poprzednim posiedzeniu Komisji.

Kolejnym wystąpieniem w drugiej części obrad plenarnych był dr Tomasz Browarek z Uniwersytetu im. Marii Curie Skłodowskiej. Dotyczyło ono podmiotów doradczych i koordynujących w polityce państwa polskiego wobec mniejszości narodowych i etnicznych po 1989 roku. Na początku swego wystapienia prelegent przedstawił kompetencje instytucji opiniodawczo-doradczych i koordynujących politykę etniczną państwa polskiego, a następnie przeszedł do analizy instytucjonalno-prawnej powstania i działalności wspomnianych podmiotów oraz procesu ich modyfikacji w okresie po 1989 roku. W referacie skupił się przede wszystkim na takich podmiotach, jak: Komisja Mniejszości Narodowych i Etnicznych Sejmu RP, Międzyresortowym Zespole do Spraw Mniejszości Narodowych, Zespół do Spraw Mniejszości Narodowych, Komisja Wspólna 
Rządu i Mniejszości Narodowych i Etnicznych oraz Radza do Spraw Przeciwdziałania Dyskryminacji Rasowej, Ksenofobii i związanej z nimi Nietolerancji. Dwa ostatnie referaty zaprezentowane podczas sesji plenarnej dotyczyły porównań rozwiązań w zakresie ochrony praw mniejszości w Polsce i Austrii oraz Czechach. Pierwszej analizy porównawczej dokonała dr Ewa Godlewska z Uniwersytetu im. Marii Curie Skłodowskiej. Na początku stwierdziła, iż zarówno w Polsce, jak i w Austrii tworzeniu ustawy dotyczącej mniejszości towarzyszyły obawy i nadzieje. Referentka wyróżniła podobieństwa oraz różnice między rozwiązaniami prawnymi zastosowanymi w obu państwach. Do pierwszych zaliczyła na przykład: odniesienie w konstytucji do praw mniejszości. Wśród różnic wyróżniła z kolei: czas przyjęcia ustawy - w Austrii był to 1976 rok, a w Polsce 2005, brak w austriackich rozwiązaniach uznania języka regionalnego (jak ma to miejsce w Polsce), indywidualne podejście do grup mniejszościowych w Austrii przejawiające się m.in. w tworzeniu dla każdej z nich Narodowościowych Rad Doradczych (czego nie ma w Polsce) oraz posługiwanie się obecnie sformułowaniem grupa narodowościowa (Volksgruppe), a nie jak ma to miejsce w Polsce mniejszość narodowa i etniczna. Konfrontacji zastosowanych rozwiązań prawnych dotyczących praw mniejszości w Polsce i Czechach dokonała z kolei dr Elżbieta Szyszlak z Uniwersytetu Wrocławskiego. Podobnie, jak jej przedmówczyni widziała więcej różnic niż podobieństw w omawianej materii. Mimo, iż jak podkreśliła Polska i Czechy były uznane za państwa narodowe, w obu państwach transformacja społeczno-polityczna dokonała się w podobnym okresie, to jednak nie przedłożyło się to na podobne rozwiązania prawne w zakresie ochrony praw mniejszości. Prelegenta zwróciła uwagę na fakt, iż Czesi nie wprowadzili sztucznego podziału na mniejszości narodowe i etniczne, jak to zastosowano w polskiej ustawie. Nie wyznaczyli cenzusu stuletniej obecności na terenie Czech, jak i nie wprowadzili do rozwiązań prawnych języka regionalnego. Na zakończenie dr E. Szyszlak przyznała, że łatwiej jest staé się mniejszością w Czech niż w Polsce.

W pierwszym dniu obrad zorganizowana została także dyskusja panelowa poświęcona przepisom ustawy o mniejszościach a oczekiwaniom Ślązaków. Część tę poprowadził dr Cezary Trosiak z Wydziału Nauk Politycznych i Dziennikarstwa UAM. W panelu wzięli udział: Dietmar Brehmer z Niemieckiej Wspólnoty Roboczej „Pojednanie i Przyszłość”, Piotr Długosz reprezentujący Stowarzyszenie Osób Narodowości Śląskiej, Jerzy Gorzelik z Ruchu Autonomii Śląska, Piotr Spyra przedstawiciel Ruchu Obywatelskiego „Polski Śląsk” oraz Waldemar Szendera ze Związku Górnośląskiego z siedzibą w Katowicach. Do uczestników panelu zostały skierowane następujące pytania: Jakie argumenty przemawiają za lub przeciw uznaniu Ślązaków za odrębną grupę etniczną́narodową?, jakie problemy w ustawie z 2005 roku zostały rozwiązane w sposób zadawalający, a które nadal czekają na rozwiązanie?, czy uznanie Ślązaków za odrębną grupę etniczną/narodową będzie początkiem procesu, w wyniku którego dojdzie do pojawienia się dążeń separatystycznych na Górnym Śląsku?

Po dyskusji panelowej zorganizowano dwa równoległe panele. Pierwszy z nich zatytułowany został „Ślązacy w poszukiwaniu tożsamości”, któremu przewodniczył prof. A. Sadowski. Drugi z kolei poświęcony został sytuacji mniejszości niemieckiej w okresie obowiązywania ustawy. Przewodniczącym tej części został prof. S. Łodziński. W panelu będącym kontynuacją wcześniejszej dyskusji wszystkie wystąpienia dedykowane były nieuznawanej prawnie w Polsce grupie, a mianowicie Ślązakom. Pierwsza głos zabrała prof. Ewa Michna z Uniwersytetu Jagiellońskiego. Swoje wystąpienie zatytułowała Pomiędzy uznaniem a wykluczeniem. Ustawa o mniejszościach narodowych i etnicznych oraz o jezyku regionalnym a aspiracje emancypacyjne Ślazaków. Prof. E. Michna stwierdziła, iż zamknięta lista mniejszości ujętych w ustawie może być narzędziem wykluczenia i odmawiania praw do ochrony nowym podmiotom zmierzającym do etnicznej emancypacji. Referentka przedstawiła spór o uznanie Slązaków. Dokonała analizy działań podejmowanych przez śląskich liderów zmierzających do emancypacji społeczności śląskiej i prawnego jej uznania oraz opisała aktywność władz państwowych, które odmawiają uznania Ślązaków. Kolejny referat zaprezentowany został wspólnie przez dr Kamillę Dolińską i dr Natalię Niedźwiecką-Iwań- 
czak z Uniwersytetu Wrocławskiego. W referacie podjęta została kwestia statusu prawnego Ślązaków, a dokładnie ich nieobecności w wielokulturowej przestrzeni, której zasięg wyznacza ustawa o mniejszościach z 2005 roku. Był to głos na gruncie socjologii, w którym autorki poszukiwały uzasadnień wyłączenia Ślązaków poza obszar ustawy i wynikających z tego konsekwencji dla powyższej grupy. Dr Kamilla Dolińska i dr Natalia Niedźwiecka-Iwańczak wskazały również koncepcje, w oparciu o które naukowy dyskurs o narodzie i grupie etnicznej obliguje do ostrożności w formułowaniu jednoznacznych rozstrzygnięć co do kierunku przeobrażeń w (auto)definiowaniu odmienności narodowej.

Analizie procesów tworzenia i odtwarzania tożsamości śląskiej po 1989 roku poświęcony był także referat dr Patrycji Bałdys z Akademii Marynarki Wojennej im. Bohaterów Westerplatte w Gdyni. Prelegentka zastanawiała się jaki wpływ miała polityka władz wobec mniejszości na wzrost mobilizacji społecznej ludności Górnego Śląska oraz na rozbudzenie aktywności ruchów regionalnych. Swoje wystapienie oparła na badaniach własnych prowadzonych od $1997 \mathrm{roku}$, jak i analizie danych zastanych. W dalszej części panelu głos zabrała reprezentantka Uniwersytetu Śląskiego, dr Małgorzata Myśliwiec. Swoje wystąpienie rozpoczęła od stwierdzenia, iż wg spisów powszechnych z 2002 i 2011 roku Ślązacy są najliczniejszą mniejszością na terenie Polski. Jak jednak podkreśliła, fakt ten nie przełożył się na żadne polityczne działania zmierzające do upodmiotowienia tej grupy w państwie polskim czy uznania ślōnskiej godki za język regionalny. Dr M. Myśliwiec poszukiwała odpowiedzi na pytania: kim są Ślązacy żyjący w państwie polskim - narodem, narodowością, czy grupą etniczną?, za kogo mogą być uznani w świetle obowiązujących w Polsce przepisów prawnych? oraz dlaczego GUS zapytał o przynależność do mniejszości śląskiej oraz o kwestię posługiwania się śląskim językiem regionalnym? Na temat społecznej, politycznej i kulturalnej emancypacji Ślązaków w okresie obowiązywania ustawy wypowiedział się także dr Tomasz Słupik z Uniwersytetu Śląskiego. Natomiast dr Cezary Trosiak z Uniwersytetu im. Adama Mickiewicza odniósł się do relacji między mniejszością niemiecką a „większością” śląską. Referent postawił tezę, iż w okresie między spisami powszechnymi z 2002 i 2011 roku mieliśmy do czynienia z systematyczną konwersją ludności deklarującej swoje niemieckie pochodzenie w kierunku opcji niemiecko-polskiej i niemiecko-śląskiej. Zjawisko to prowadziło, jak podkreślił dr C. Trosiak, do konfliktu między mniejszością niemiecką skupioną wokół Towarzystwa Społeczno-Kulturalnego Niemców z województwa opolskiego a Ruchem Autonomii Śląska i Stowarzyszeniem Osób Narodowości Śląskiej.

Poza panelem poświęconym Ślązakom równolegle odbywał się panel dotyczący sytuacji mniejszości niemieckiej w okresie obowiązywania ustawy. Część tą zainaugurowało wystapienie prof. Aleksandry Trzcielińskiej-Polus z Uniwersytetu Opolskiego zatytułowane Mniejszość niemiecka na Ślasku Opolskim - atut czy wyzwanie dla regionu? Na wstępie referentka odniosła się do specyfiki tego regionu szczególnie pod względem jego wielokulturowości, czyli współżycia ludności polskiej, niemieckiej, śląskiej i przesiedleńców z Kresów. Następnie poszukiwała odpowiedzi na pytanie dotyczące wyzwań stawianych przed władzami regionu oraz jego mieszkańcami w związku z realizacją praw przysługujących mniejszości niemieckiej na mocy ustawy o mniejszościach narodowych i etnicznych z 2005 roku? Prof. A. Trzcielińska-Polus w swoim referacie położyła nacisk na postrzeganie aktywności politycznej Towarzystwa Społeczno-Kulturalnego Niemców na Śląsku Opolskim oraz problemy związane z pielęgnowaniem niemieckiego dziedzictwa kulturowego. Z kolei mniejszości niemieckiej zamieszkującej teren Dolnego Śląska swój referat dedykowała dr Irena Kurasz z Uniwersytetu Wrocławskiego. Zaznaczyła ona, iż uznanie mniejszości narodowych znajduje się paradoksalnie zamiast w fazie rozkwitu, to w okresie stagnacji. Przyczyn tej sytuacji upatrywała w: wieloletniej polityce dyskryminacyjnej i asymilacyjnej władz PRL oraz procesach demograficznych powodujących starzenie się tych społeczności. Wymienione zjawiska, jak podkreśliła, ściśle przedkładały się na trudności związane z poprawnym zastosowaniem metodologii badań mniejszości narodowych. Dr I. Kurasz wiele miejsca poświęciła również na omówienie kwestii związanych z precyzyjnym określeniem badanej populacji (kto jest 
Niemcem?), następnie z prowadzeniem badań w organizacjach reprezentujących mniejszość niemiecką, problemami związanymi z dotarciem i pozyskaniem respondentów do badań oraz z opracowaniem danych. Kontynuatorką tematyki związanej z mniejszością niemiecką była dr Marta Jas-Koziarkiewicz z Uniwersytetu Warszawskiego. Przedmiotem jej wystąpienia była kwestia prezentacji na łamach czasopisma „Wochenblatt.pl” w 2014 roku informacji dotyczących zakresu realizacji praw zawartych w ustawie o mniejszościach narodowych i etnicznych oraz o języku regionalnym. Referentka uznała, iż najczęściej na łamach tego niemieckiego czasopisma odwoływano się do spraw związanych z używaniem podwójnych nazw miejscowości, szkolnictwem w języku niemieckim, posługiwaniem się językiem niemieckim jako pomocniczym w urzędach czy funkcjonowaniem pełnomocnika wojewody ds. mniejszości. Ostatnim referentem w tej części był dr Paweł Popieliński z Polskiej Akademii Nauk z Warszawy. Swoje wystapienie zatytułował Wplyw Ustawy o mniejszościach narodowych i etnicznych oraz o języku regionalnym na funkcjonowanie środowiska mniejszości niemieckiej w Polsce. Odniósł się w nim do zagadnienia wpływu rozwiązań prawnych zawartych w ustawie z 2005 roku na rzeczywistość mniejszości niemieckiej zamieszkującej Górny Śląsk, Dolny Śląsk, Warmię, Mazury, Pomorze i Ziemię Lubuską. Szczególną uwagę zwrócił na oświatę mniejszości niemieckiej, promowanie dwujęzyczności w tym środowisku oraz proces wprowadzania podwójnego nazewnictwa na tablicach topograficznych.

Pierwszy dzień obrad uświetnił program artystyczny w wykonaniu przedstawicieli mniejszości w Polsce.

Piątek, 8 maja był drugim i zarazem ostatnim dniem obrad konferencji. Został on podzielony na dwie części, z których pierwsza dotyczyła odniesień do mniejszości etnicznych, a druga wpływie ustawy na różne aspekty aktywności mniejszości narodowych i etnicznych. Pierwszej z nich przewodniczył dr Cezary Trosiak. Trzy spośród sześciu referatów wygłoszonych w tym panelu poświęconych zostało Kaszubom. Część tę otwierało wystąpienie zatytułowane Jesteśmy narodem? Kaszubskie dyskusje nad tożsamościq w kontekście ustawy o mniejszościach z 2005 roku. Jego autorką była prof. Katarzyna Warmińska z Uniwersytetu Jagiellońskiego. Ze względów zdrowotnych Pani profesor nie mogła jednak osobiście uczestniczyć w konferencji, ale jej referat zaprezentował dr Tomasz Wicherkiewicz z Uniwersytetu im. Adama Mickiewicza. Główna uwaga wystąpienia skupiona była na tej części kaszubskiej społeczności, która kontestuje istniejący stan rzeczy, czyli fakt przyznania Kaszubom miana społeczności posługującej się językiem regionalnym. Jak podkreśliła w swoim wystąpieniu zwolennicy kaszubskiej opcji narodowej dążą do zmiany przepisów ustawy. Chcą, aby Kaszubi otrzymali status mniejszości etnicznej. Problematyka tej społeczności kontynuowana była następnie przez prof. Monikę Mazurek-Janasik z Uniwersytetu Gdańskiego. W jej ocenie prawne uznanie języka kaszubskiego za język regionalny w ustawie z 2005 roku było niewątpliwie sukcesem. To dzięki ustawie, jak podkreśliła Pani profesor, Kaszubi mogli rozpocząć aktywność w dziedzinie nauczania języka kaszubskiego, który uznawany jest za wyznacznik kaszubskiej tożsamości etnicznej. Ponadto wprowadzenie w życie postanowień ustawy o mniejszościach zmobilizowało tę społeczność do działań oraz afirmacji swojej tożsamości. Następnie głos zabrał Prezes Zrzeszenia Kaszubsko-Pomorskiego mgr Lukasz Grzędzicki. Wystąpił w roli praktyka, prezentując aktywność społeczności kaszubskiej na Pomorzu w okresie 10 lat obowiązywania ustawy o mniejszościach. Kolejną mniejszością etniczną, do której odniesiono się w tej części panelu byli Łemkowie. Grupie tej swoją uwagę poświęciła dr Beata Orłowska z Akademickiego Centrum Badań Euroregionalnych przy PWSZ im. Jakuba z Paradyża w Gorzowie Wielkopolskim. Przestawiła ona aktywność społeczną Łemków zamieszkujących powiat strzelecko-drezdencki. Przedostatni referat przed przerwą dotyczył z kolei mniejszości romskiej. Na tej społeczności skupiła się prof. Anita Adamczyk z Uniwersytetu im. Adama Mickiewicza. Na początku przedstawiła tezę, iż ustawa z 2005 roku nie wpłynęła w znaczący sposób na funkcjonowanie Romów w Polsce. Jak podkreśliła, na przeszkodzie stała przede wszystkim tradycja i kultura romska, która uniemożliwiała korzystanie z przepisów ustawy. Wspomniała także 
o propozycjach zmian ustawy rekomendowanych przez Stowarzyszenie Romów w Polsce oraz nowelizacji ustawy w 2014 roku. Swoją uwagę poświęciła również programom wspierającym mniejszość romską w okresie obowiązywania ustawy o mniejszościach. Ostatni referat Etniczne polityki miejskie. Na marginesie ustawy wygłosiła dr hab. Julita Makaro z Uniwersytetu Wrocławskiego. Prelegentka odniosła się w nim do ograniczonej funkcjonalności ustawy w stosunku do faktycznego zróżnicowania kulturowego i etnicznego w Polsce. Uznała, iż zjawisko wielokulturowości jest skomplikowane i obejmuje stare, jak i nowe mniejszości, czyli imigrantów. Ustawa z 2005 roku odnosi się tylko do tej pierwszej grupy, a w stosunku do pozostałej jest nie rozwiązana (poza kwestiami pobytu i zarobkowania). W końcowej części swojej wypowiedzi zwróciła uwagę na zróżnicowanie etniczne w miastach.

Druga część obrad, w dniu 8 maja, poświęcona została wpływie ustawy na różne aspekty aktywności mniejszości narodowych i etnicznych. Przewodniczenie jej powierzono prof. A. Trzeieińskiej-Polus. Pierwszą prelegentką była dr Ewa Pogorzała reprezentująca Państwową Wyższą Szkołę Zawodową im. Szymona Szymonowica w Zamościu. W swoim referacie położyła nacisk na stan i wyzwania stojące przed systemem nauczania języków i w językach mniejszości w Polsce. Zwróciła uwagę na aspekt historyczno-prawny wprowadzania nauki języka mniejszości oraz jej instytucjonalny wymiar. Kolejny głos zabrał dr Norbert Honka z Uniwersytetu Opolskiego, który zajął się wpływem ustawy z 2005 roku na funkcjonowanie samorządu terytorialnego na przykładzie województwa opolskiego. Swoją uwagę skupił przede wszystkim na: wprowadzeniu języka pomocniczego do urzędów, używaniu dwujęzycznych tablic topograficznych oraz wykorzystaniu środków z subwencji na naukęjęzyka mniejszości w województwie opolskim. Następnie swój referat wygłosiła dr Barbara Kobzarska-Bar z Wyższej Szkoły Handlowej we Wrocławiu. Zajęła się Ona podmiotowością polityczną mniejszości narodowych i etnicznych z punktu widzenia teorii zasobów organizacji. Dr B. Kobzarska-Bar uznała, iż badanie tego zagadnienia umożliwia znalezienie odpowiedzi na pytania dotyczące współczesnego statusu mniejszości w przestrzeni politycznej oraz prognozowania zmian koniecznych dla zachowania i rozwoju mniejszości. Wiele miejsca w swoim referacie Pani doktor poświęciła analizie podmiotowości politycznej na przykładzie mniejszości niemieckiej. Kontynuacją problematyki podjętej w ww. referacie było wystąpienie mgr Doroty Kowalewskiej z Uniwersytetu Szczecińskiego. Prelegentka skupiła się na depolityzacji organizacji mniejszości narodowych i etnicznych funkcjonujących na terenie województwa zachodniopomorskiego. Przez depolityzację rozumiała świadome wycofanie się mniejszości z życia politycznego. Mgr D. Kowalewska podjęła się także próby odpowiedzi na pytania czy mniejszości narodowe i etniczne nieobecne w życiu politycznym regionu doświadczają depolityzacji wynikającej z określonych czynników zewnętrznych oraz czy jest to świadoma strategia podtrzymywania własnej odrębności kulturowej?

Innym zagadnieniom związanym z mniejszościami narodowymi i etnicznymi poświęcony był kolejny referat. Dotyczył on ujęcia kwestii mniejszości w ramach nauki społecznej Kościoła katolickiego w Polsce. Jego autorem był dr Paweł Stachowiak z Uniwersytetu im. Adama Mickiewicza. Referent rozpoczął swoje wystąpienie od prezentacji historycznego kontekstu stosunku Kościoła katolickiego w Polsce do mniejszości narodowych w okresie II RP i PRL. Następnie odniósł się do konkretnych działań duszpasterskich struktur kościelnych w środowiskach mniejszości niemieckiej, romskiej i litewskiej w ostatnim dziesięcioleciu. Ostatnim referatem wygłoszonym na konferencji była problematyka dotycząca aktywności pełnomocnika ds. mniejszości narodowych i etnicznych - urzędu ustanowionego mocą art. 22 ust. 3 ustawy o mniejszościach. Przedstawił go mgr Patryk Pawełczak z Uniwersytetu im. Adama Mickiewicza. Swoją uwagę skupił przede wszystkim na: roli wojewody w ustawie z 2005 roku, umiejscowieniu pełnomocnika do spraw mniejszości narodowych i etnicznych w urzędach wojewódzkich, współdziałaniu pełnomocników z przedstawicielami organizacji pozarządowych, organami administracji samorządowej realizującymi zadania na rzecz mniejszości, jak i wdrażaniu programów dotyczących mniejszości narodowych i etnicznych. 
Podsumowania konferencji dokonał prof. Andrzej Sakson. Przyznał on, że to dwudniowe spotkanie było intelektualną ucztą dla naukowców i praktyków zajmujących się zagadnieniami mniejszości narodowych i etnicznych oraz osób posługujących się językiem kaszubskim. Majowe spotkanie zorganizowane z okazji 10 lat obowiązywania ustawy o mniejszościach bez wątpienia było refleksją nad rozwiązaniami prawnymi zastosowanymi w ustawie oraz wykorzystaniem ich w praktyce. Konferencja ta stała się także forum dla wypracowania nowych standardów w polityce etnicznej oraz zmian w ustawie z 2005 roku.

Anita ADAMCZYK

Poznań 